Received: 09-07-2021

(Date-Month-Year)
Revised: 27-09-2021

(Date-Month-Year)
Published: 30-10-2021

(Date-Month-Year)

\title{
BERPIKIR KREATIF SISWA KEMAMPUAN MATEMATIKA TINGGI DALAM MEMECAHKAN MASALAH KONTEKSTUAL
}

\author{
Ucik Fitri Handayani ${ }^{1}$ \\ ${ }^{1}$ Tadris Matematika, Institut Agama Islam Al-Qolam Malang \\ 13ucik@alqolam.ac.id
}

\begin{abstract}
Abstrak: Kemampuan berpikir kreatif sangat dibutuhkan siswa dalam memecahkan masalah kontekstual matematika. Tujuan penelitian ini adalah untuk mendeskripsikan kemampuan berpikir kreatif siswa berkemampuan matematika tinggi dalam memecahkan masalah matematika kontekstual. Penelitian ini merupakan penelitian kualitatif deskriptif. Fokus penelitian ini yakni pada siswa kelas VIII yang rata-rata nilai UAS di kelasnya lebih tinggi dari pada kelas lain. Pengumpulan data dilakukan dengan tes dan wawancara. Hasil jawaban siswa dianalisis menggunakan indikator fluency, flexibility, dan novelty. Kemudian dikategorikan berdasarkan tingkat berpikir kreatif. Terdapat 2 siswa kemampuan tinggi yang dipilih sebagai subjek penelitian. Hasil penelitian ini adalah (1) Terdapat siswa berkemampuan matematika tinggi yang berada pada tingkat 4 (sangat kreatif) yang memenuhi 3 indikator yakni kelancaran, keluwesan dan kebaruan dengan baik sesuai materi dan kemampuannya. (2) Terdapat siswa kemampuan tinggi berada pada tingkat 3 (kreatif) yang memenuhi 2 indikator yakni kelancaran dan keluwesan dengan baik sesuai materi dan kemampuannya. (3) Siswa kelompok kemampuan tinggi memiliki tingkat yang berbeda sesuai kemampuan dan pengetahuan siswa.

Katakunci: Kreativitas; Masalah Kontekstual; Matematika.
\end{abstract}

\begin{abstract}
The purpose of this study was to describe high student creativity in solving contextual mathematics problems. This study focused on class VIII students whose class average was higher than other classes. The data was collected by means of tests and interviews. The results of the students' answers were analyzed using indicators of fluency, flexibility, and novelty. Then, they were categorized based on the creativity level. There were 2 high ability students selected as research subjects. The results of this study were (1) There were high ability students who are in level 4 (very creative) by fulfilling 3 indicators, namely fluency, flexibility and novelty according to their material and abilities. (2) There were high ability students who are only at level 3 (creative) by fulfilling only 2 indicators, namely fluency and flexibility according to their material and abilities. (3) There were indicators of novelty that are not fulfilled by high ability students. (4) Students of high ability groups had different level according to students' abilities and knowledge. (5) The lack of creativity of high-skilled students was because students do not understand contextual problems due to insufficient practice questions.
\end{abstract}

Keywords: Creativity; Contextual Issues; Mathematics

\section{Pendahuluan}

Tuntutan pada Abad 21 mewajibkan siswa untuk dapat menguasai berbagai kemampuan. Sebagaimana dijelaskan bahwa pendidikan pada abad 21 membawa paradigma pembelajaran yang mengharuskan lulusan memiliki keterampilan berpikir tingkat tinggi (Nasution et al. 2017). Pembaharuan kurikulum harus dilakukan demi terwujudnya kompetensi abad 21 pada seluruh bidang studi khususnya matematika. Sebagaimana yang diketahui bahwa matematika pasti ada di semua tingkat pendidikan yang erat kaitannya dengan kehidupan. Kompetensi dasar dalam matematika penting untuk dimiliki karena diperlukan dalam banyak kegiatan 
rutin sehari-hari (Ekstam et al. 2018). Sehingga, dalam hal ini mengakibatkan proses pembelajaran matematika harus dilaksanakan secara optimal agar tujuan tercapai.

Kompetensi yang sebaiknya dimiliki siswa khususnya jenjang SMP/MTs dalam menghadapi tantangan abad 21 salah satunya yakni kemampuan berpikir kreatif. Tujuan pendidikan sekolah di tingkat apa pun harus mampu menumbuhkan kemampuan berpikir kreatif, logis, dan pemecahan masalah (Švecová, Rumanová, and Pavlovičová 2014). Seperti pendapat Amelia and Pujiastuti (2020) dimana dalam persaingan global kompetensi berpikir kreatif wajib dimiliki siswa. Untuk dapat mengembangkan kemampuan tersebut, siswa perlu diberikan masalah matematika yang menantang dan tidak rutin.

Berpikir kreatif sebagai salah satu kompetensi wajib pada diri siswa termuat di tujuan pembelajaran matematika pada satuan pendidikan. Secara sederhana yang dimaksud dengan kreatif merupakan suatu kegiatan yang menghasilkan hal baru, dan orang lain belum memikirkannya (Yusnaeni et al. 2016). Berpikir kreatif matematis menuntut siswa untuk dapat menciptakan sebuah solusi benar bersifat baru yang tidak "biasa" atau "unik". Lince (2016) menjelaskan bahwa apabila siswa dapat menyelesaikan soal matematika yang tergolong soal non rutin menggunakan strategi berbeda dari penjelasan dan contoh guru pada proses pembelajaran disebut kreatif.

Berpikir kreatif yang ditunjukkan siswa dalam memecahkan masalah memang perlu dikembangkan. Sriraman, Haavold, and Lee (2013) mengutarakan bahwa pemecahan masalah menjadi bagian dari berpikir kreatif. Pemikiran kreatif dapat diciptakan apabila seorang guru menciptakan lingkungan belajar yang mendukung munculnya keterampilan berpikir (Yusnaeni et al. 2016). Nadjafikhah et al. (2012) menegaskan bahwa guru harus mengidentifikasi berpikir kreatif matematika siswa. Satuan pendidikan dan guru tentu berperan penting dalam mewujudkan tujuan pembelajaran. Menurut Daud et al. (2012) sekolah merupakan tempat paling penting untuk mengasah bakat dan berpikir kreatif siswa.

Terkait dengan berpikir kreatif siswa dapat diupayakan melalui sebuah pembiasaan dalam setiap proses pembelajaran matematika. Menurut Sa'dijah (2013) kegiatan belajar mengajar matematika dapat mendorong berpikir kreatif siswa dalam memecahkan masalah matematika serta dalam memutuskan suatu pilihan. Yang berperan paling utama dalam mengembangkan berpikir kreatif siswa adalah guru dalam setiap pembelajarannya (Suastika, 2017). Siswono (2011) menjelaskan bahwa berpikir kreatif diartikan sebagai kegiatan menghasilkan hasil (produk) bersifat baru yang bermanfaat dan dapat dimengerti/dipahami oleh semua orang. Kreativitas dikenal sebagai produk berpikir kreatif matematis dalam bidang matematika, hal ini dikarenakan keduanya memiliki pengertian yang sama (Siswono, 2011). Lince (2016) mengutarakan bahwa sebelum siswa memecahkan masalah tentunya akan berpikir untuk mencari serta memilih ide matematika yang cocok dan sesuai, sehingga menjadi sebuah hasil (produk) dari berpikir kreatif.

Diperlukan indikator untuk digunakan mendeskripsikan kemampuan berpikir kreatif siswa. Azhari and Somakim (2013) menyebutkan empat indikator meliputi kelancaran, keluwesan, original, dan elaborasi. Selain itu, Silver dalam (dalam Handayani, Sa'dijah, and Susanto 2018) menggunakan 3 penilaian 
diantaranya yakni fluency, flexibility, dan novelty. Pencapaian indikator menggambarkan siswa untuk memaknai permasalahan dengan menuliskan berbagai solusi/jawaban dengan benar tanpa adanya kesulitan. Akan tetapi, yang terjadi di lapangan tidak sesuai.

Saat observasi dilaksanakan ditemukan informasi bahwa siswa SMP memiliki latar belakang yang berbeda baik secara akademis. Pada materi pelajaran matematika terdapat perbedaan kemampuan matematika siswa di kelas. Terdapat 3 kelompok kemampuan matematika siswa, yakni kemampuan matematika tinggi, sedang, dan rendah. Pengelompokkan tersebut didasarkan pada rata-rata nilai UAS siswa di kelas. Dalam penelitian ini dipilih 2 siswa kemampuan matematika tinggi berdasarkan nilai UAS tertinggi dan kemampuan komunikasi siswa dalam menjelaskan.

Berdasarkan hasil observasi terdapat beberapa hal yang ditemui yakni masih menggunakan ceramah atau guru menjadi pusat, metode, model pembelajaran serta media/benda konkret yang digunakan masih belum beragam karena media terbatas, siswa kurang aktif dan berpikir kreatif siswa yang berbedabeda. Selanjutnya berdasarkan wawancara, terdapat beberapa siswa mengatakan bahwa merasa bingung jika dihadapkan dengan soal cerita seperti masalah kontekstual yang memiliki berbagai jawaban benar.

Masalah kontekstual penting untuk dilatihkan kepada siswa. Hal ini dikarenakan dalam masalah kontekstual merupakan masalah yang dialami siswa dalam kehidupan sehari-hari dan sangat realistik bagi siswa. Masalah kontekstual yang disajikan oleh guru dalam pembelajaran dapat melatih dan mengelaborasi keterampilan berpikir tingkat tinggi siswa dengan kata lain Higher Order Thinking Skills (HOTS).
HOTS penting bertujuan untuk menganalisis, mengevaluasi, dan membuat, sehingga siswa memiliki kemapuan kreatif (Apino and Retnawati 2017). Guru sains khususnya matematika memiliki kesadaran akan pentingnya HOTS dan juga mengetahui bahwa pembelajaran yang menekankan HOTS sesuai dalam mewujudkan kompetensi abad 21 (Afandi et al. 2018).

Kemampuan berpikir kreatif tiap siswa berbeda sesuai pengetahuan dan kemampuan yang dimilikinya. Terkait perbedaan tersebut, peneliti melakukan penelitian terkait berpikir kreatif siswa berkemampuan tinggi. Penelitian ini penting untuk dilaksanakan untuk untuk mendeskripsikan berpikir kreatif siswa kemampuan matematika tinggi dalam memecahkan masalah matematika kontekstual. Dengan hal ini guru dapat menginovasi proses pembelajaran matematika selanjutnya untuk melatihkan kemampuan berpikir matematis siswa.

\section{Metode Penelitian}

Subjek penelitian deskriptif kualitatif ini adalah siswa kelas VIII yang rata-rata nilai UAS di kelasnya lebih tinggi dari kelas lain. Sebelum penentuan subjek penelitian, siswa pada kelas tersebut dikelompokkan sesuai kemampuan awal matematika yakni kemampuan tinggi, sedang dan rendah berdasarkan rata-rata nilai UAS dari wali kelas. Kemudian dipilih 2 subjek berkemampuan matematika tinggi berdasarkan rata-rata nilai UAS dan kemampuan komunikasi ssiswa dalam menjelaskan. Pengumpulan data dilakukan melalui tes dan wawancara.

Pada tes yang dilakukan, terdapat 2 masalah matematika kontekstual yang harus dikerjakan oleh siswa. Soal tersebut disusun berdasarkan indikator berpikir kreatif dan telah divalidasi oleh ahli bidang matematika, yaitu seorang dosen 
matematika pasca sarjana Universitas Negeri Malang dan seorang guru matematika di SMP. Hasil tes dianalisis berdasarkan indikator kemampuan berpikir kreatif matematis yaitu fluency, flexibility dan novelty kemudian dilanjutkan pengkategorian berdasarkan tingkat berpikir kreatif siswa.

Indikator Kelancaran (fluency) dilihat dari bagaimana siswa siswa yang dapat menuliskan berbagai solusi/jawaban benar dan lancar tanpa adanya kesulitan. Indikator keluwesan (flexibility) dilihat dari bagaimana siswa menuliskan satu strategi pemecahan masalah atau berbagai strategi pemecahan masalah secara terurut dan dapat menjelaskan proses memecahkannya. Indikator kebaruan (novelty) dilihat dari bagaimana siswa dapat menuliskan solusi/jawaban/strategi pemecahan masalah matematika yang tampak berbeda dengan yang digunakan biasanya pada pembelajaran di kelas. Berikut disajikan pedoman dan deskripsi tingkat berpikir kreatif siswa pada Tabel 1 .

Tabel 1. Deskripsi Tingkat Berpikir Kreatif

\begin{tabular}{lccc}
\hline Tingkat Kreativitas & $\begin{array}{c}\text { Kelancaran } \\
\text { (fluency) }\end{array}$ & $\begin{array}{c}\text { Keluwesan } \\
\text { (flexibility) }\end{array}$ & $\begin{array}{c}\text { Kebaruan } \\
\text { (novelty) }\end{array}$ \\
\hline Tingkat 4 (Sangat Kreatif) & $\sqrt{ }$ & $\sqrt{ }$ & $\sqrt{ }$ \\
Tingkat 3 (Kreatif) & $\sqrt{ }$ & - & - \\
Tingkat 2 (Cukup Kreatif) & - & $\sqrt{ }$ & - \\
Tingkat 1 (Kurang Kreatif) & - & - & $\sqrt{ }$ \\
Tingkat 0 (Tidak Kreatif) & $\sqrt{ }$ & - & - \\
\hline
\end{tabular}
Sumber : Siswono (2011)

\section{Hasil dan Pembahasan}

Siswa kelas VIII dikelompokkan sesuai dengan kemampuan awal matematika berdasarkan daftar nilai dari guru. Selanjutnya siswa kelompok kemampuan tinggi diberikan tes untuk menentukan tingkat berpikir kreatif siswa. Dipilih 2 subjek penelitian berdasarkan hasil tes dan kelacaran komunikasi saat dilakukan wawancara. Subjek yang dipilih yakni Subjek S-3 dan Subjek S-23.

Berikut jawaban subjek S-3 pada tes untuk indikator kelancaran dapat dilihat pada Gambar 1. 


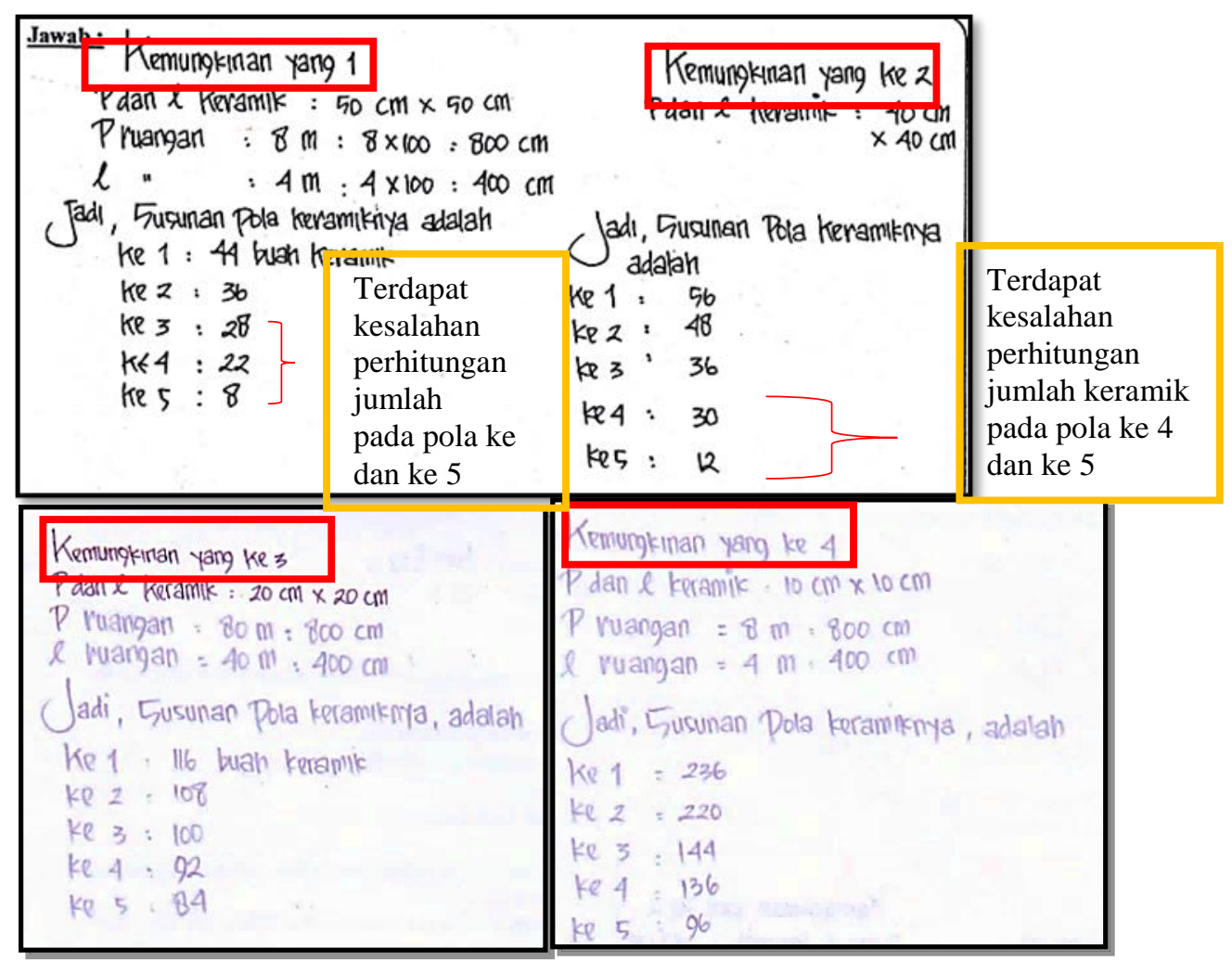

Gambar 1. Jawaban Subjek S-3 pada Indikator Kelancaran

Berdasarkan hasil pekerjaan subjek S-3 pada indikator kelancaran dapat menuliskan jawaban lebih dari satu kemungkinan yaitu empat kemungkinan ukuran disertai dengan jumlah keramik pada masing-masing pola dengan benar dan lancar. Jumlah keramik yang dituliskan oleh subjek S-3 pada setiap pola kemungkinan 3 dan 4 sudah benar, namun pada kemungkinan 1 dan 2 pola ke 4 dan ke 5 ada kesalahan perhitungan jumlah.

Berdasarkan hasil wawancara subjek S-3 juga menjelaskan dan menyatakan jumlah keramik pada setiap pola membentuk sebuah pola bilangan. Subjek S-3 dapat memecahkan masalah pada tes nomor soal 1 dengan menggunakan strategi menemukan pola. Untuk menemukan pola subjek S-3 menghitung jumlah keramik pada bagian panjang dan lebar ruangan dengan membagi panjang dan lebar ruangan dengan ukuran keramik yang digunakan, kemudian menjumlah semua keramik yang ada pada pola ke-1. Strategi yang digunakan untuk memperoleh jumlah keramik pada bagian lebar yakni dengan membagi lebar ruangan dengan ukuran keramik yang digunakan kemudian hasilnya dikurangi dua keramik pada bagian pojok kanan sama pojok kiri agar tidak dihitung dobel karena sudah dihitung ikut jumlah keramik bagian panjang ruangan. Berdasarkan penemuan jumlah keramik pada pola ke-1, subjek S3 menemukan pola untuk mengetahui jumlah keramik pada pola ke-2 dan seterusnya yakni panjang dan lebar pada pola selanjutnya diperoleh dari pola sebelumnya dikurangi 2 keramik kemudian dijumlahkan semua.

Subjek S-3 memahami maksud dari soal sehingga dapat menuliskan beberapa kemungkinan jawaban dengan lancar dan benar. Selain itu, juga dapat 
menjelaskan proses pengerjaan dengan lancar dan jelas dan yakin dengan jawabannya.

Subjek S-23 dapat menuliskan jawaban lebih dari satu yakni dua kemungkinan ukuran disertai jumlah keramik pada setiap pola dengan benar dan lancar. Dari hasil wawancara diperoleh informasi bahwa subjek S-23 memecahkan masalah pada tes untuk nomor soal 1 dengan menggunakan strategi menemukan pola diawali dengan cara mencoba-coba. Terlebih dahulu subjek S-3 menentukan ukuran keramik yang digunakan yakni $20 \mathrm{~cm} \times 20 \mathrm{~cm}$, kemudian menghitung jumlah keramik pada sisi panjang dan lebar dan menjumlahkan seluruhnya. Dari pola ke1 subjek S-23 menemukan polanya, sehingga dapat menentukan jumlah keramik pada pola ke-2 dan seterusnya dengan menggunakan pola yang telah ditemukan.

Berdasarkan hal tersebut, subjek S-23 paham dan dapat memaknai soal, sehingga dapat menuliskan jawaban dengan lancar dan benar. Subjek S-23 dapat menjelaskan bagaimana proses pengerjaan dengan jelas dan yakin dengan jawabannya. Subjek S-23 menjelaskan proses pengerjaan dengan menentukan jumlah keramik pada setiap pola di bagian panjang terlebih dahulu kemudian pada bagian lebar. Selanjutnya subjek S-23 menjumlahkan semua keramik pada masing-masing pola. Dalam hal ini subjek S-3 dan subjek S-23 memenuhi indikator kelancaran (fluency).

Berikut jawbaan subjek S-3 pada tes untuk indikator keluwesan (flexibility) dapat dilihat pada Gambar 2.
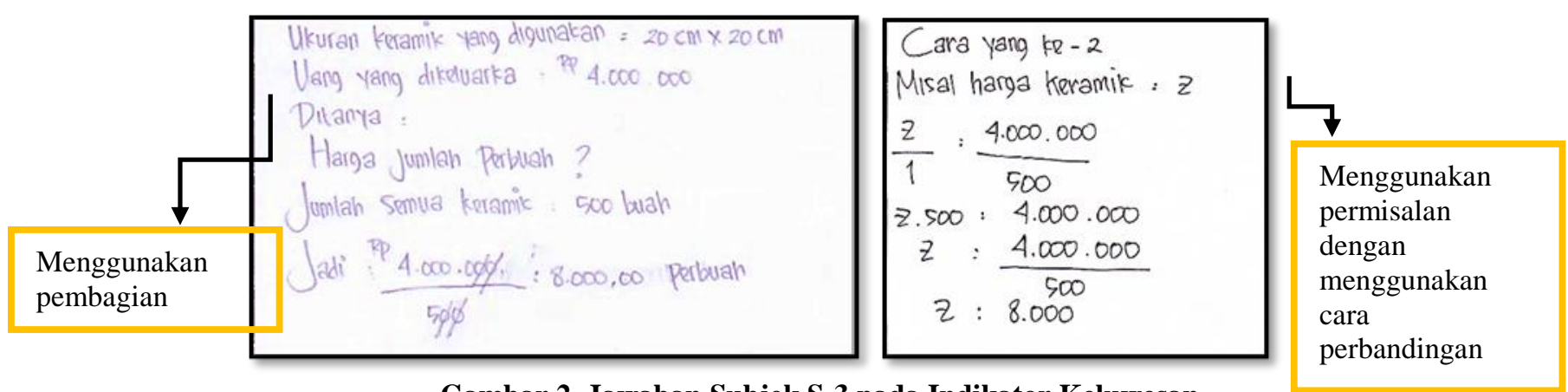

\section{Gambar 2. Jawaban Subjek S-3 pada Indikator Keluwesan}

Berdasarkan hasil pekerjaan subjek S-3 pada pada indikator keluwesan dapat menuliskan dua strategi pemecahan masalah dengan benar yakni dengan menuliskan keseluruhan informasi kemudian menggunakan cara pembagian dan memanipulasi objek atau permisalan dengan menggunakan cara perbandingan untuk mencari harga tiap keramik yang dibutuhkan dengan urut dan jelas disertai penjelasan.

Berdasarkan hasil wawancara, subjek S-3 memecahkan masalah pada tes untuk soal nomor 2 dengan menggunakan dua strategi pemecahan masalah yakni menuliskan keseluruhan informasi dengan menggunakan cara pembagian dan memanipulasi objek atau permisalan dengan menggunakan cara perbandingan.

Melalui wawancara, subjek S-3 yakin bahwa ide yang digunakan untuk memecahkan masalah tersebut merupakan ide terbaik yang dapat digunakan, subjek S-3. Alasan mengapa subjek S-3 yakin dengan dua strategi yang digunakan itu benar adalah pada saat melihat hasil akhir yang ditemukan sama antara menggunakan cara pembagian ataupun menggunakan cara perbandingan.

Berikut jawaban subjek S-23 pada tes untuk indikator keluwesan (flexibility) dapat dilihat pada Gambar 3. 


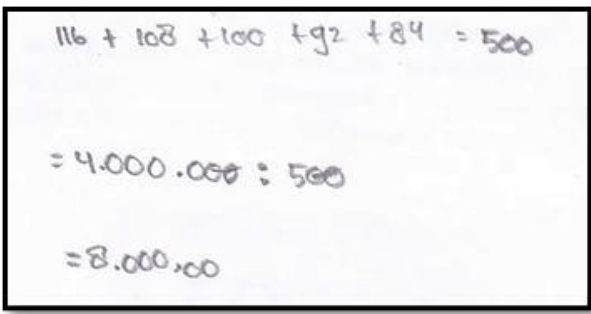

Gambar 3. Jawaban Subjek S-23 pada Indikator Keluwesan

Berdasarkan hasil pekerjaan subjek S-23 dapat menuliskan satu strategi pemecahan masalah yakni menuliskan keseluruhan informasi dengan menggunakan cara pembagian dengan urut dan benar. Dari hasil wawancara, diperoleh informasi bahwa subjek S-23 memecahkan masalah pada tes untuk soal nomor 2 dengan menggunakan cara pembagian Dalam hal ini subjek S-23 dapat memahami maksud dari soal, sehingga dapat menuliskan jawaban dengan benar. Subjek S-23 hanya menuliskan satu strategi pemecahan masalah dengan terurut dan jelas, hal ini dikarenakan subjek S-23 tidak mengetahui cara lain dalam memecahkan masalah tersebut. Subjek S23 yakin bahwa ide yang digunakan untuk memecahkan masalah itu adalah ide terbaik yang dapat digunakan namun tidak mengetahui cara lain untuk memecahkan masalah. Dalam hal ini, subjek S-3 dan S-23 memenuhi indikator keluwesan (flexibility).

Berikut jawaban subjek S-3 pada tes untuk indikator kebaruan (novelty) dapat dilihat pada Gambar 4.

\begin{tabular}{|l} 
Cara yang kr-2 \\
Misal harga keramik : $z$ \\
$\frac{z}{1}: \frac{4.000 .000}{500}$ \\
$z .500: 4.000 .000$ \\
$z: \frac{4.000 .000}{500}$ \\
$z: 8.000$
\end{tabular}

Gambar 4. Jawaban Subjek S-3 pada Indikator Kebaruan
Berdasarkan hasil pekerjaan subjek S-3 pada indikator kebaruan menuliskan salah satu strategi pemecahan masalah yang sedikit berbeda yakni dengan memanipulasi objek atau melakukan sebuah permisalan dengan menggunakan cara perbandingan. Melalui wawancara, subjek S-3 menjelaskan bahwa subjek S3 memecahkan masalah pada tes dengan menggunakan strategi pemecahan masalah yang sedikit berbeda dengan yang lain. Subjek S-3 menjelaskan bahwa sebelumnya tidak pernah mendapatkan strategi pemecahan masalah seperti ini pada materi pola bilangan. Subjek S-3 juga tidak mengetahui cara lain selain yang pernah diajarkan oleh guru. Subjek S-3 juga yakin bahwa dengan memanipulasi objek dengan menggunakan cara perbandingan dapat digunakan dalam memecahkan masalah ini, karena jawaban yang didapatkannya sama dengan menggunakan cara pembagian. Selanjutnya dalam hal ini, subjek S-3 memenuhi indikator kebaruan (novelty).

Subjek S-23 memecahkan masalah pada tes dengan strategi yang tidak berbeda. Melalui wawancara, subjek S-23 merasa kesulitan memahami masalah kontekstual, sehingga tidak mengetahui cara lain yang berbeda dalam penyelesaiannya. Hal ini dikarenakan kurangnya latihan untuk memecahkan masalah kontekstual yang menuntut berbagai jawaban benar. Akibatnya, subjek S-23 tidak memenuhi indikator kebaruan (novelty).

Hasil jawaban siswa kemampuan tinggi dapat memenuhi indikator fluency, flexibility, dan novelty, sehingga tingkat berpikir kreatif siswa berada pada tingkat 4 yang artinya subjek S-3 termasuk siswa sangat kreatif. Selanjutnya subjek yang memenuhi indikator fluency, flexibility dan belum memenuhi indikator novelty, sehingga subjek S-23 berdasarkan tingkat berpikir kreatif berada pada tingkat 3 
yang artinya subjek S-23 termasuk siswa

terdapat pada Tabel 2 .

kreatif. Ringkasan hasil penelitian

Tabel 2. Ringkasan Hasil Tes

\begin{tabular}{ccccc}
\hline \multirow{2}{*}{ Subjek } & \multicolumn{3}{c}{ Indikator } & \multirow{2}{*}{ Tingkat Kreativitas } \\
\cline { 2 - 4 } & Kelancaran & Keluwesan & Kebaruan & \\
\hline S-3 & $\checkmark$ & $\checkmark$ & $\checkmark$ & Tingkat 4 (sangat kreatif) \\
\hline S-23 & $\checkmark$ & $\checkmark$ & - & Tingkat 3 (kreatif) \\
\hline
\end{tabular}

Berdasarkan Tabel 2, subjek S-3 memenuhi tiga indikator. Siswa dapat menjawab permasalahan dengan menuliskan kemungkinan jawaban benar berbeda-beda dengan lancar, dapat menuliskan lebih dari satu strategi dalam memecahkan masalah, dapat menjelaskan langkah pengerjaan dengan jelas, urut, dan lancar, sehingga berada pada tingkat 4 (sangat kreatif). Hasil ini sejalan dengan hasil penelitian Mustakim dan Budiarto (2017) dimana siswa dengan kemampuan tinggi memenuhi ketiga indikator yakni kelancaran, keluwesan, dan kebaruan secara maksimal. Sependapat dengan Damayanti dan Sumardi (2018) dalam penelitiannya yang menerangkan bahwa siswa kemampuan tinggi dan sedang dapat mencapai indikator kelancaran dan keluwesan, namun indikator kebaruan hanya dicapai oleh siswa kemampuan tinggi.

Subjek S-3 dapat memenuhi indikator kelancaran dengan menuliskan jawaban lebih dari satu kemungkinan. Dalam penelitian Syahara dan Astutik (2021) siswa yang memenuhi indikator kelancaran yakni dapat memberikan alternatif solusi penyelesaian yang beragam dan bernilai benar. Subjek S-3 dapat menenuhi indikator keluwesan dengan menuliskan dua strategi pemecahan masalah dengan benar. Dalam penelitian Syahara dan Astutik (2021) siswa yang memenuhi indikator keluwesan dapat menyelesaikan masalah matematika dengan menggunakan cara yang berbeda-beda serta memiliki penyelesaian benar. Subjek S-3 juga dapat memenuhi indikator kebaruan. Dalam penelitian Syahara dan Astutik (2021) siswa yang memenuhi indikator kebaruan dapat menyelesaikan masalah matematika yang diberikan dan cara yang digunakan tidak biasa dilakukan seperti siswa lain. Dalam hal ini, semakin sedikit siswa yang memberikan jawaban atau cara yang sama, maka tingkat kebaruannya semakin tinggi (Mursidik, Syamsiyah, dan Rudyanto, 2014)

Subjek S-23 memenuhi dua indikator yakni kelancaran dan keluwesan. Siswa dalam penyelesaian masalah dapat menuliskan kemungkinan jawaban benar berbeda-beda dengan lancar, dapat menuliskan satu strategi pemecahan masalah dalam memecahkan masalah dengan urut, dapat menjelaskan langkah pengerjaan dengan jelas, dan tidak menuliskan strategi berbeda dalam memecahkan masalah, sehingga berada pada kategori tingkat 3 (kreatif). Sujarwo dan Yunianta (2018) menerangkan bahwa terdapat satu siswa dengan kemampuan tinggi masuk dalam kategori tingkat 4 (sangat kreatif), sedangkan siswa yang satunya berada pada tingkat 3 (kreatif).

Terdapat siswa kemampuan tinggi yang tidak dapat memenuhi indikator kebaruan. Sebagaimana hasil penelitian Andiyana, Maya, dan Hidayat (2018) dimana siswa tidak mampu memenuhi indikator originality karena tidak dapat menuliskan jawaban yang dimaksud soal. Sependapat dengan Damayanti dan Sumardi (2018) dalam penelitiannya yang menerangkan bahwa siswa kemampuan tinggi dan sedang mencapai indikator kelancaran dan keluwesan. Menurut Herdani dan Ratu (2018) subjek berkemampuan matematika tinggi belum tentu dikategorikan kreatif.

Pada penelitian ini siswa yang memiliki kemampuan tinggi berada pada 
kategori tingkat 4 (sangat kreatif) dan tingkat 3 (kreatif). Meskipun subjek kelompok kemampuan tinggi berada pada kelompok yang sama tetapi memiliki kategori kemampuan berpikir kreatif matematis yang berbeda. Kedua subjek ini mempunyai karakteristik hasil jawaban yang berbeda pada indikator kebaruan (novelty). Sejalan dengan Muthaharah, Kriswandani, dan Prihatnani (2018) dimana hasil penelitiannya yang menyatakan bahwa berpikir kreatif matematis siswa tidak sama walaupun tingkat pendidikan sama, bahkan masih ada siswa yang belum memenuhi ketiga indikator. Biasanya dengan kemampuan awal yang tinggi maka tingkat berpikir kreatifnya pun cenderung tinggi (Utami dan Kuneni 2016). Leikin dan Lev (2013) juga menambahkan bahwa terdapat hubungan antara siswa kemampuan tinggi dengan kemampuan berpikir kreatif matematis. Akibatnya, tingginya kemampuan awal siswa maka tingkat berpikir kreatifnya juga semakin tinggi.

Berpikir kreatif siswa
berkemampuan matematika tinggi dalam memecahkan masalah kontekstual menunjukkan lebih menggunakan strategi menemukan pola, siswa cenderung memecahkan masalah kontekstual dengan menuliskan kemungkinan jawaban lebih dari satu dan strategi pemecahan masalahanya pun juga lebih dari, siswa mengerjakan soal secara rinci dan lengkap, tak banyak siswa yang dapat menuliskan jawaban berbeda/unik dari yang lain, dan siswa dalam memecahkan masalah kontekstual yang belum pernah ditemui dan dijelaskan strategi pemecahan masalah, maka siswa tetap mengerjakan dengan caranya sendiri.

\section{Kesimpulan}

Berdasarkan kajian teori, paparan data hasil dan pembahasan, didapatkan kesimpulan: (1) Siswa kelompok kemampuan tinggi dapat memenuhi tiga indikator yakni kelancaran, keluwesan dan kebaruan sesuai materi dan kemampuannya, sehingga berada pada tingkat 4 (sangat kreatif). (2) Siswa kelompok kemampuan tinggi dapat memenuhi dua indikator kemampuan berpikir kreatif matematis siswa yakni kelancaran dan keluwesan sesuai materi dan kemampuannya, sehingga berada pada tingkat 3 (kreatif). (3) Siswa kelompok kemampuan tinggi memiliki tingkat yang berbeda-beda sesuai kemampuan dan pengetahuan siswa.

Berpikir kreatif siswa diharapkan dapat menjadi acuan guru dalam memberikan latihan soal sesuai dengan kemampuan siswa. Guru juga disarankan untuk terbiasa memberikan masalah matematika kontekstual tidak rutin yang bersifat terbuka dengan berbagai jawaban benar dan strategi beragam untuk membiasakan kemampuan berpikir kreatif matematis siswa. Diharapkan ada penelitian lanjutan untuk membiasakan siswa memecahkan masalah dengan berbagai jawaban benar, sehingga berpikir kreatif menjadi meningkat.

\section{Daftar Pustaka}

Journal article:

Afandi, Afandi, Sajidan Sajidan, Muhammad Akhyar, and Nunuk Suryani. 2018. "Pre-Service Science Teachers' Perception About High Order Thinking Skills (HOTS) in the 21st Century." International Journal of Pedagogy and Teacher Education 2(1):107. doi: 10.20961/ijpte.v2i1.18254.

Amelia, Syela Rizki, and Heni Pujiastuti. 2020. "Analisis Kemampuan Berpikir Kreatif Matematis Melalui Tugas Open-Ended." Jurnal Pembelajaran Matematika Inovatif 3(3):247-58. doi: 10.22460/jpmi.v3i3.247-258.

Andiyana, Muhamad Arfan, Ripi Maya, 
and Wahyu Hidayat. 2018. "Analisis Kemampuan Berpikir Kreatif Matematis Siswa Pada Materi Bangun Ruang." JPMI (Jurnal Pembelajaran Matematika Inovatif) 1(3):239-. doi: 10.22460/jpmi.v1i4.p779-784.

Apino, E., and H. Retnawati. 2017. "Developing Instructional Design to Improve Mathematical Higher Order Thinking Skills of Students." Pp. 17 in Journal of Physics: Conference Series.

Azhari, and Somakim. 2013. "Peningkatan Kemampuan Berpikir Kreatif Matematik Siswa Melalui Pendekatan Konstruktivisme Di Kelas VII Sekolah Menengah Pertama (SMP) Negeri 2 Banyuasin III." Jurnal Pendidikan Matematika 7(2):1-12.

Damayanti, Herwinanda Trisnaning, and Sumardi Sumardi. 2018. "Mathematical Creative Thinking Ability of Junior High School Students in Solving Open-Ended Problem." JRAMathEdu (Journal of Research and Advances in Mathematics Education) 3(1):36. doi:

10.23917/jramathedu.v3i1.5869.

Daud, Adzliana Mohd, Jizah Omar, Punia Turiman, and Kamisah Osman. 2012. "Creativity in Science Education." Procedia - Social and Behavioral Sciences 59:467-74. doi: 10.1016/j.sbspro.2012.09.302.

Dwi Herdani, Pendawi, and Novisita Ratu. 2018. "Analisis Tingkat Kemampuan Berpikir Kreatif Matematis Siswa SMP Dalam Menyelesaikan Open - Ended Problem Pada Materi Bangun Datar Segi Empat." JTAM | Jurnal Teori Dan Aplikasi Matematika 2(1):9. doi: 10.31764/jtam.v2i1.220.

Ekstam, Ulrika, Johan Korhonen, Karin Linnanmäki, and Pirjo Aunio. 2018.
"Special Education and Subject Teachers' Self-Perceived Readiness to Teach Mathematics to LowPerforming Middle School Students." Journal of Research in Special Educational Needs 18(1):59-69. doi: 10.1111/14713802.12393.

Handayani, Ucik Fitri, Cholis Sa'dijah, and Hery Susanto. 2018. "Analisis Kemampuan Berpikir Kreatif Matematis Siswa SMP Dalam Menyelesaikan Soal Adopsi 'PISA.'" Jurnal Math Educator Nusantara 4(2):143. doi: 10.29407/jmen.v4i2.12109.

Leikin, Roza, and Miriam Lev. 2013. "Mathematical Creativity in Generally Gifted and Mathematically Excelling Adolescents: What Makes the Difference?" ZDM - International Journal on Mathematics Education 45(2):183-97. doi: 10.1007/s11858012-0460-8.

Lince, Ranak. 2016. "Creative Thinking Ability to Increase Student Mathematical of Junior High School by Applying Models Numbered Heads Together." Journal of Education and Practice 7(6):20612.

Mursidik, Elly's Mersiina, Nur Syamsiyah, and Hendra Erik Rudyanto. 2014. "Analisis Kemampuan Berpikir Kreatif Siswa Sd Dalam Memecahkan Masalah Matematika." Jurnal LPPm 2(2):713.

Mustakim, and Mega teguh Budiarto. 2017. "Identifikasi Kreativitas Siswa SMP Dalam Menyelesaikan Masalah Luas Segiempat." MATHEdunesa Jurnal Ilmiah Pendidikan Matematika 2(6):26668.

Muthaharah, Yhana Alfianadevi, Kriswandani, and Erlina Prihatnani. 
2018. "Analisis Kemampuan Berpikir Kreatif Matematis Siswa Smp Dalam Menyelesaikan Soal Bangun Ruang Sisi Datar." Jurnal Mitra Pendidikan 2(1):11-22.

Nadjafikhah, Mehdi, Narges Yaftian, and Shahrnaz Bakhshalizadeh. 2012. "Mathematical Creativity: Some Definitions and Characteristics." Pp. 285-91 in Procedia - Social and Behavioral Sciences. Vol. 31.

Nasution, Tetty Khaerani, Edy Surya, Asmin, and Bornok Sinaga. 2017. "An Analysis of Student ' s Mathematical Creative Thinking Ability Senior High School on Geometry." Ijariie 3(2):3860-66.

Sa'dijah, Cholis. 2013. "Kepekaan Bilangan Siswa SMP Melalui Pembelajaran Matematika Kontekstual Yang Mengintegrasikan Keterampilan Berpikir Kreatif." Jurnal Pendidikan Dan Pembelajaran 20(2):222-27.

Siswono, Tatag Yuli Eko. 2011. "Level of Student's Creative Thinking in Classroom Mathematics." Educational Research and Review 6(7):548-53.

Sriraman, Bharath, Per Haavold, and Kyeonghwa Lee. 2013. "Mathematical Creativity and Giftedness: A Commentary on and Review of Theory, New Operational Views, and Ways Forward." ZDM International Journal on Mathematics Education 45(2):21525.

Suastika, Ketut. 2017. "Mathematics Learning Model of Open Problem Solving to Develop Students , Creativity." 12(6):569-77.

Sujarwo, Eko, and Tri Nova Hasti Yunianta. 2018. "Analisis Kemampuan Berpikir Kreatif Siswa Kelas VIII SMP Dalam Menyelesaikan Soal Luas Bangun." Jurnal Kajian Pembelajaran
Matematika (JKPM) 2(1):1-9.

Švecová, Valéria, Lucia Rumanová, and

Gabriela Pavlovičová. 2014.

“Support of Pupil's Creative

Thinking in Mathematical

Education." Procedia - Social and

Behavioral Sciences 116:1715-19.

doi: 10.1016/j.sbspro.2014.01.461.

Syahara, Masita Ulil, and Erna Puji

Astutik. 2021. "Analisis Berpikir

Kreatif Siswa Dalam Menyelesaikan

Masalah SPLDV Ditinjau Dari

Kemampuan Matematika."

Mosharafa: Jurnal Pendidikan

Matematika 10(2):201-12.

Utami, Aliksia Kristiana Dwi, and Erna

Kuneni. 2016. "Analisis Tingkat

Kemampuan Berpikir Kreatif Pada

Materi Geometri Ditinjau Dari

Kemampuan Awal.” Pp. 351-61 in.

Yusnaeni, Herawati Susilo, A. D.

Corebima, and Siti Zubaidah. 2016.

"Hubungan Kemampuan Berpikir

Kreatif Dan Hasil Belajar Kognitif

Pada Pembelajaran Search Solve

Create and Solve Di SMA."

Prosiding Seminar Nasional Biologi

2016 (January 2018):443-46. 